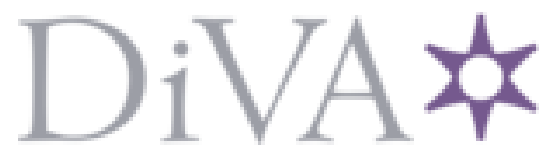

http://www.diva-portal.org

This is the published version of a paper published in European Journal of Scandinavian Studies.

Citation for the original published paper (version of record):

Aronsson, M. (2015)

"Jag satt till bords med de bästa". Interkulturella möten i Vilhelm Ekelunds verk.

European Journal of Scandinavian Studies, 45(1): 35-59

Access to the published version may require subscription.

N.B. When citing this work, cite the original published paper.

Permanent link to this version:

http://urn.kb.se/resolve?urn=urn:nbn:se:du-17282 


\title{
Mattias Aronsson
}

\section{"Jag satt till bords med de bästa". Interkulturella möten i Vilhelm Ekelunds verk}

\begin{abstract}
The Swedish poet, essayist and aphorist Vilhelm Ekelund wrote extensively on the topic of foreign authors. Some of these writers represent the Greek and Roman cultural heritage; some belong to the modern-day literary canon. This article investigates the nature of these "intercultural encounters" in Ekelund's body of work. By processing data from Andar i den Ekelundska sfären (1989) and Konkordans till Vilhelm Ekelunds skrifter (2000), we have been able to count all references made to the most important individuals appearing in Ekelund's texts. At the top end of the table we find such prominent writers as Goethe (1343 references), Nietzsche (985) and Plato (503 references). We show that Ekelund's oeuvre is largely dominated by male authors and philosophers of Western cultural heritage: the most prominently figured foreign nationalities being German (20,7\%), Greek (10,1\%), French (9,2\%) and Roman (5,4\%) writers. The quantitative method applied in our study is a good complement to more textcentered approaches to literature. In this case, it allows us to determine, with a great deal of accuracy, the extent and nature of the intercultural encounters in Vilhelm Ekelund's body of work.
\end{abstract}

DOI 10.1515/ejss-2015-0003

\section{Introduktion}

Ett centralt begrepp i Vilhelm Ekelunds författarskap är "möte” och av speciellt intresse är författarens egna möten med viktiga föregångare och förebilder ur litteraturhistorien. I synnerhet i de essäistiska och aforistiska texterna diskuterar han ständigt tankar och idéer ur andra skapares verk. Ekelunds förhållande till de stora heroerna är personligt och ikonoklastiskt. Han möter dem oftast med entusiasm, ibland har han reservationer att framföra och någon gång är han polemisk och hånfull i sin kritik. Men hans läsningar karakteriseras alltid av engagemang och intensitet. "Möte” är även en central aspekt av interkulturalitetsbegreppet, eftersom denna term tar fasta på just kontakterna mellan olika kulturer och interaktionen dem emellan. Nationalencyklopedin preciserar exem-

Mattias Aronsson: Högskolan Dalarna, S-791 88 Falun, E-Mail: mar@du.se 
pelvis att adjektivet interkulturell "avser processer där människor med olika språk och kulturer kommunicerar och interagerar med varandra." ${ }^{1}$

Föreliggande artikel behandlar Vilhelm Ekelunds umgänge med de stora andarna ur litteraturhistorien. Jag betraktar Ekelunds verk som en mötesplats mellan författaren och hans förebilder från skilda tider och kulturer, och därigenom blir hans skrifter också intressanta att studera utifrån ett interkulturellt perspektiv. Jag koncentrerar studien till de möten som uppstår mellan den svenskspråkige författaren Vilhelm Ekelund och skriftställare från andra länder och språkområden. Därmed blir språk, geografisk härkomst och, i viss mån, etnicitet de mest centrala aspekterna i min förståelse av interkulturalitetsbegreppet. ${ }^{2}$

Vilka interkulturella möten uppstår då i Vilhelm Ekelunds texter? Vilka författares liv och verk sysselsatte hans tankar så intensivt att de fann en väg in i författarskapet? Ja, att döma av vad han själv anger rör det sig helt enkelt om de bästa skaparna som världslitteraturen kan uppbringa: "Jag satt till bords med de bästa; jag fröjdade mig beständigt åt det stora" skriver han exempelvis $\mathrm{i}$ Sak och sken (1922: 24) och citerar då Goethe. Även i Det andra ljuset (1935: 107) uttrycker han en liknande åsikt, i det att han slår fast: "Sökt af de bästes tankar: så besökt låg hvarje sann ensamhet."

Vilhelm Ekelunds förhållande till vissa särskilt viktiga författarskap har redan kartlagts av forskarsamfundet. ${ }^{3}$ Dessa studier ger av naturliga orsaker be-

1 http://www.ne.se/interkulturell. (Substantivet "interkulturalitet” figurerar ej som uppslagsord i NE.)

2 Interkulturalitet kan förstås också inbegripa kommunikation och interaktion mellan individer av olika kön, klass, ålder och sexuell läggning - men i denna artikel kommer fokus inte att ligga på sådana faktorer. Jag använder mig heller inte av termen "transkulturalitet” i föreliggande arbete. De som begagnar sig av detta begrepp brukar intressera sig explicit för kulturers instabilitet och hybridisering. Se t. ex. Welsch (1999) vars idéer har varit viktiga för transkulturalitetsbegreppets utformning. Se också en nyligen publicerad volym som Transcultural Identities in Contemporary Literature (red. Gilsenan Nordin m.fl., 2013) som exempel på studier där man, i Welschs efterföljd, använder sig av begreppet och applicerar det på moderna författarskap. Transkulturalitet är enligt min mening ett utmärkt redskap för att beskriva just moderna samhällsförhållanden och vid läsning av nyare tiders litteratur, men det är mindre användbart i en analys av Vilhelm Ekelunds verk. Ekelund levde och verkade i en tid då "kultur", "folk" och "nation" var relativt fasta, entydiga och föga problematiserade begrepp. Det som intresserade honom var olika kulturers särarter och förhållandena dem emellan. Se exempelvis Harald Elovson (1966: 28) som noterar att författaren var "upptagen av relationen mellan olika kulturer" och att han gärna arbetade med "föreställningen om olika nationallynnen". Ekelund var heller inte främmande för att använda sådana abstraktioner som florerade i dåtidens diskurs - "rasmedvetenhet" och "rasinstinkt" för att nämna två (På hafsstranden, 1922: 42 och 53) - men som idag anses helt förlegade.

3 Exempelvis har Rolf Ekman (1951 resp. 1976) studerat Vilhelm Ekelunds förhållande till Nietzsche och Platon, Harald Elovson (1966 och 1968) har intresserat sig för författarens relation till 
tydligt mer detaljerade upplysningar om vilket inflytande de enskilda konstnärerna haft på Ekelunds skapande än vad denna artikel kan ge. Mitt mål här är tvärtom att ge en övergripande bild av författarens möten med de för honom viktigaste skriftställarna. En sådan forskningsansats har egentligen bara Nils Gösta Valdén (1971) tidigare använt sig av. ${ }^{4}$ Min förhoppning är att föreliggande studie kan komplettera Valdéns undersökning, eftersom jag till skillnad från honom också använder mig av visst statistiskt källmaterial och presenterar kvantitativa data. ${ }^{5}$ I det följande kommer jag exempelvis att visa siffror på vilka nationaliteter som dominerar bland de individer som omnämns i Ekelunds verk, samt exakt hur många gånger olika författares namn nämns i dessa skrifter. Det har varit möjligt att fastställa tack vare data från Andar i den Ekelundska sfären (1989) och Konkordans till Vilhelm Ekelunds skrifter (2000), material som inte fanns tillgängligt när Valdén publicerade sin studie.

Tyngdpunkten i undersökningen ligger på de interkulturella möten som kan skönjas i Ekelunds eget författarskap. Innan jag behandlar detta huvudområde vill jag dock med några ord beröra den rent biografiska interkulturaliteten, samt den som uppstår i Ekelunds översättningar.

\section{Biografisk interkulturalitet}

Vilhelm Ekelund föddes i skånska Stehag år 1880 och trots att han kom från en enkel hantverkarbakgrund, hans far var smed, fick han möjlighet att studera

Rousseau, Carl-Henning Wijkmark (1976) för Stefan George, Claes Schaar (1976 resp. 1990) för Dante och Emerson, Eva-Britta Ståhl (1999) för Hölderlin, Lars Bergquist (1999) för Swedenborg, Gunnar D. Hansson (2002) för Thorild och Per Erik Ljung (2009) för relationen till Strindberg, Kant, Swedenborg och Leopardi. Därutöver berör Algot Werin i sin Ekelundbiografi (utgiven i två band, 1960 och 1961) författarens förhållande till åtskilliga stora föregångare: Stagnelius, Platen, Hölderlin, Ola Hansson, Goethe, Nietzsche, Emerson, Dostojevskij, Mäster Eckhart, Platon och Swedenborg - för att endast nämna de skriftställare vars namn återfinns i kapitelrubrikerna.

4 Se artikeln "Vilhelm Ekelund och världslitteraturen" publicerad i Vetenskapssocieteten $i$ Lund. Årsbok 1971: 142-156.

5 Min forskningsmetod sätter alltså delvis fokus på kvantitativa aspekter som numerärer och procentandelar. Därigenom uppvisar den vissa likheter med den metod som Pierre Naert använder sig av i sin avhandling Stilen i Vilhelm Ekelunds essayer och aforismer (1949). Naerts studie är på många vis ett imponerande pionjärarbete. Dels var det den första doktorsavhandling inriktad på Vilhelm Ekelunds författarskap som publicerades, dels använde han sig av en kvantitativ forskningsansats i en tid då all materialinsamling och -bearbetning med nödvändighet måste ske för hand, eftersom datorn ännu inte fanns tillgänglig som hjälpmedel för forskaren. 
vid läroverk i Lund. I likhet med andra läroverkspojkar på helklassisk linje fick han en gedigen genomgång av det antika kulturarvet. Många ungdomar av denna studiegång må ha betraktat "latindrillen" som ett nödvändigt ont på vägen mot vuxenliv och karriär, så var emellertid inte fallet med Vilhelm Ekelund. Det klassiska bildningsstoffet gjorde uppenbarligen ett så starkt intryck på honom att han aldrig släppte det ur sikte under återstoden av sitt liv. I efterhand nämner han vid ett tillfälle Julius Caesars De bello gallico som en tidig och speciellt viktig bildningsupplevelse. ${ }^{6}$ I Båge och lyra (1912: 193-194) hyllar han också den romerska litteraturen, och det latinska språket, i högstämda ordalag:

Till sist är kanske den romerska litteraturen den djupaste tröst-, kraft- och hälsokälla, som någonsin bjudits människoanden. Hvilken egendomlig fysiologisk effekt har icke redan själfva språket, det latinska! Jag tror att ens nervsystem skulle undergå en genomgripande förändring, om man vande sig att tänka på latin! Jag iakttar detta särskildt eklatant, när jag oväntadt midt i en modern text träffar ett romerskt citat. Det är som trädde jag ut på en klippafsats och plötsligt den majestätiska hafshorisonten slöte sig om min själ.

På ett annat ställe framstår istället grekisk och tysk litteratur som de viktigaste inspirationskällorna för honom. Ekelund skriver nämligen att han tackar sin lyckliga stjärna "som låtit tyskt väsen jämte Hellas blifva min lyckligaste upplefvelse." (Hemkomst och flykt, 1972: 42.)

Allt kunskapsstoff som den unge Vilhelm tog till sig förmedlades dock inte av skolan. Faktum är att han av studentbetyget att döma inte var någon vidare flitig elev (se t. ex. Werin, 1960: 39 och Valdén, 1961: ix). Det ligger nära till hands att anta att den unge mannen inte lade all sin energi på att studera de texter som stod på skolans obligatoriska läslista, utan sökte sin andliga spis också långt utanför pensum. Det är åtminstone vad som antyds i "Oroligt blod", en tidig prosatext skriven i tredje person men med tydligt självbiografiska inslag, varav några utdrag sedermera trycktes i Hemkomst och flykt (1972) och som nyligen (2013) för första gången har publicerats i sin helhet:

Han hade föresatt sig att blott använda just så mycket arbete på läxor, som var absolut nödvändigt för den regelbundna flyttningen, och den planen utförde han lyckligt med det resultat, att hans studentbetyg visserligen var blott i jämnaste lag tillfredsställande, men att han, då skoltiden var slut, satt inne med en litteraturkännedom, som för hans ålder kunde anses synnerligen vidsträckt. (Oroligt blod, 2013: 37.)

De interkulturella inslagen i Vilhelm Ekelunds biografi fram till tjugoårsåldern var således huvudsakligen av indirekt natur, $i$ betydelsen att de alla var läse-

6 "Den dag han nått fram till Caesars första sats - Gallia est omnis divisa in partes tres - då for det som en marsblåst igenom en ordentlig pojkes bröst!” (Hemkomst och flykt, 1972: 20.) 
frukter. Tiden efter läroverksåren saknar dock inte direkta interkulturella kopplingar. Efter debuten som poet år 1900 tillbringade han flera längre perioder utomlands. Fr.o.m. 1902 reste den unge diktaren med viss regelbundenhet till Tyskland och skrev reportage och artiklar från bl. a. Berlin, Hamburg och Kiel. Även en längre resa till Venedig hann Ekelund med under nittonhundratalets första år. Han skrev under sin diktarperiod ett relativt stort antal artiklar för publicering i pressen, i huvudsak baserade på upplevelser och intryck från tiden på kontinenten. Eftersom en del av dessa texter senare trycktes om i bokform i Böcker och vandringar (1910) och Tyska utsikter (1913) är det uppenbart att de tidiga Tysklandsvistelserna har gjort betydande avtryck i författarens produktion. ${ }^{7}$ Som ung poet var han också influerad av tyska diktare som Richard Dehmel och Stefan George. Han visade öppet sin uppskattning för dessa lyriker, bland annat genom att dedicera dikter till dem.

Från 1908 var Vilhelm Ekelund permanent bosatt i Tyskland, mestadels i Berlin men under en tid även i Hamburg. ${ }^{8}$ Från och med 1912 fortsatte exilen i Danmark. Han gifte sig med en danska och paret fick en dotter år 1914. Familjen stannade i Danmark till 1921. Vilhelm Ekelund tillbringade alltså en sammanhängande period på tretton år utomlands, till vilken ska läggas ytterligare en Danmarksvistelse 1930-1934. Under alla dessa exilår levde han naturligtvis omgiven av tysk (respektive dansk) kultur, och det tyska (respektive danska) språket dominerade i hans omgivning. De långa vistelserna utomlands bidrog rimligen till många interkulturella möten och lämnade sannolikt också vissa avtryck i författarens stil. Det är exempelvis inte svårt att spåra såväl tysk- (stavningen av egennamnet) som danskspråkig (användningen av verbet "lida") påverkan i följande anteckning från år 1915: ”För första gång läst Tschekhoff. 'Mitt lif'. [...] Därpå 'Bönder'. Den lämnar intet öfrigt att önska. Ja, sådant kan jag lida.” (Hemkomst och flykt, 1972: 61-62.) ${ }^{9}$

Ändå finns det, enligt min mening, ingen anledning att överdriva biografins betydelse i Ekelunds fall, åtminstone inte den påverkan som författarens bostadsort eventuellt kan tänkas ha haft på hans skapande. Snarare gäller nog följande sanning: varhelst Vilhelm Ekelund befann sig kroppsligen, var han andligen i samspråk med sina heroer. Och deras kulturella hemvist berodde i

7 Många artiklar och reportagetexter från denna tid som inte fann sin väg in i ovannämnda volymer publicerades postumt i Den ensammes stämningar. Artiklar och dikter 1898-1910 (1984).

8 Han lämnade Sverige i september 1908, för att slippa avtjäna ett månadslångt fängelsestraff som han tilldömts för våld mot tjänsteman (se t. ex. Werin, 1960: 324-327 och 410).

9 Se även Veri similia II (1916: 96) för ett exempel på en snarlik danism: "Gamla solkiga böcker kan jag godt lida”. 
mycket liten utsträckning på om Ekelund själv vistades i Tyskland, Danmark eller i Sverige.

\section{Översättningarnas interkulturalitet}

En första indikation om vilka utländska författarskap som var viktiga för Vilhelm Ekelund kan man få genom att se på vilka författare han valde att översätta till svenska och på så vis göra tillgängliga för en svenskspråkig publik. Översättningsakten är ju per definition en interkulturell handling i och med att översättaren i sitt arbete låter två språk och kulturer mötas.

Vilhelm Ekelund tolkade under sina tidiga diktarår Baudelaires prosapoem "L'Étranger" och hade för avsikt att överföra hela verket Le Spleen de Paris till svenska. Hans förlag Bonniers ställde sig dock avvisande till dessa planer, vilket gjorde att hela projektet rann ut i sanden. ${ }^{10}$ Ekelund tolkade också under tidigt 1900-tal några dikter av skotten Robert Burns, och även av den tidigare nämnda tyske poeten Richard Dehmel. Dessa dikter figurerar insprängda bland Ekelunds originalpoem i samlingen Syner (1901).

År 1906 utkom översättningsvolymen Grekisk bukett, med tolkningar av ett antal grekiska epigram. I dessa översättningar tog sig Ekelund an bl. a. Platon, Simonides, Anyte, Asklepiades, Leonidas, Kallimachos och Meleager. Ekelund skulle som bekant tystna som poet efter denna publikation och inte återvända till den litterära scenen förrän tre år senare, och då som prosaförfattare. Därmed kan man betrakta den lilla samlingen tolkningar som en bro till det senare författarskapet, genom att Ekelunds djupa förtrogenhet med klassisk grekisk kultur här framstår explicit. Detta tema skulle ju senare både fördjupas och utvidgas i prosatexter som Antikt ideal (1909) och Båge och lyra (1912).

Också som prosaförfattare skulle Vilhelm Ekelund fortsätta att översätta utländska författare. År 1913 gav han ut en första översättningsvolym på prosa: Giocomo Leopardi: Valda skrifter. Svensk översättning med en inledning om Leopardi av Vilhelm Ekelund. ${ }^{11}$ Några år senare, 1915, kom ytterligare ett verk i den här kategorin: Ur Francesco Petrarcas brev. Med en inledning: Petrarca och Schopenhauer av Vilhelm Ekelund. År 1925, efter hemkomsten till Sverige, publ-

10 Dikten ifråga, ”Främlingen”, trycktes år 1902 i den lundensiska kulturtidskriften Majgrefven men fick inte plats i någon av de lyriksamlingar som Ekelund gav ut under åren 1900-1906. I bokform publicerades den först 1970 i Hjärtats vaggvisor. Efterlämnade dikter. Se t. ex. Jonas Ellerströms (2004a: 286) kommentarer i Ekelunds Samlade dikter I.

11 Dessa Leoparditolkningar har nyligen för första gången blivit föremål för ingående studier, se Tobias Dahlkvist (2010a och 2010b). 
icerade Ekelund den lilla volymen Väst-Östligt, utgiven till hundraårsminnet av den tyske författaren Jean Pauls dödsdag. Verket inleds med översättningar till svenska av ett antal av Jean Pauls aforismer. I början av 1930-talet kom Ekelund överens med professor John Landquist om att till skriftserien De filosofiska mästerverken bidra med tolkningar av den tyske författaren Georg Christoph Lichtenbergs aforismer, samt med översättningar av prosastycken av Ralph Waldo Emerson. Arbetet tycks dock inte ha haft högsta prioritet. Det dröjde nämligen ända till mars 1942 innan Ekelund överlämnade Lichtenbergöversättningarna, ${ }^{12}$ och Emersonmaterialet levererades överhuvudtaget aldrig till uppdragsgivaren. De gavs heller inte ut $\mathrm{i}$ någon annan form under Ekelunds livstid, men har $\mathrm{i}$ efterhand sammanställts, kommenterats och publicerats i bokform av Claes Schaar. ${ }^{13}$

Vi kan alltså konstatera att Vilhelm Ekelund var kapabel att översätta från franska (Baudelaire), klassisk grekiska (epigrammen i Grekisk bukett), italienska (Leopardi), latin (Petrarca), engelska (Emerson och Burns) samt från tyska språket (Dehmel, Jean Paul och Lichtenberg). Man vet att han också läste verk från alla dessa kultursfärer på originalspråken. Ekelunds språkkunskaper, åtminstone vad gäller färdigheter som läsförståelse och översättning till modersmålet, får därför anses vara ytterst goda.

Några av de översatta författarna tillhör de viktigare, om än inte de allra viktigaste, av Ekelunds litterära "samtalspartner”. Baudelaire var en inspirationskälla huvudsakligen under åren som diktare, men redan vid tiden runt Antikt ideal (1909), när Ekelund bröt med lyriken för att övergå till prosa, tog han också i mångt och mycket avstånd från den franske poeten. ${ }^{14}$ Också Richard Dehmel skulle försvinna så gott som fullständigt från Ekelunds horisont efter det att svensken tystnat som lyriker. ${ }^{15}$

Francesco Petrarca sysselsatte framför allt Ekelunds tankar under en period efter brytningen med poesin. Denne nämns flitigt exempelvis i Antikt ideal och i Veri similia (1915). ${ }^{16}$ Och under samma tid utgavs som sagt Ekelunds översättningar av ett urval av Petrarcas brev. Hans namn förekommer sammanlagt med

12 Se Brev 1917-1949, 1970: 177. Översättningarna av Lichtenbergs aforismer publicerades sedermera som utlovats i De filosofiska mästerverken. VII, Kant och romantikens tyska tänkare, 1946: 167-186.

13 Se Levande möte. Vilhelm Ekelunds Emersontolkningar. Med inledning och kommentar av Claes Schaar, 1990.

14 I en tidigare artikel (Aronsson, 2009: 91-92) har jag visat hur Baudelaire hör till den kategori författare från den romanska kultursfären som tydligast kritiseras i de tidiga prosaverken från perioden 1909-1919.

15 Se t. ex. Andar i den Ekelundska sfären, 1989: 23.

16 Jfr Andar i den Ekelundska sfären, 1989: 56. 
ett knappt hundratal träffar i Ekelunds verk (se Konkordans till Vilhelm Ekelunds skrifter, bd 4, 2000: 5818) vilket indikerar att han förvisso är en viktig författare för svensken, men inte tillräckligt viktig för att slå sig in på listan över de 30 oftast omnämnda individerna (se tabell 2 nedan). Detsamma gäller för övrigt Jean Paul och Lichtenberg.

Giacomo Leopardi utövade ett stort och varaktigt inflytande på Ekelund. Den italienske tänkarens påverkan på det tidiga prosaförfattarskapet kan knappast överskattas. Ett tecken på det intresse som Ekelund skänkte honom är att en större essä i Antikt ideal (1909) och en annan i Böcker och vandringar (1910) ägnas åt hans diktning. ${ }^{17}$ Även i det sena verket förblir Leopardi viktig. Hans namn dyker exempelvis upp i Atticism-humanism (1943) och In silvis cum libro (postum, 1957), och av tabell 2 framgår att Leopardi placerar sig på elfte plats i listan över de författare vars namn oftast figurerar i Ekelunds skrifter.

Den av de översatta skriftställarna som utövade allra störst inflytande på Ekelunds författarskap, och som även placerar sig högst av dessa i min lista (tabell 2), är dock amerikanen Ralph Waldo Emerson. Ekelund började förvisso inte studera honom förrän i "mogen ålder" 1912,18 men med tiden utkristalliserades han till en skapare som i Ekelunds värld kunde länkas till självaste Goethe. De karakteriseras båda, enligt svensken, av en lugn och solig optimism, en kontroll över affekterna och en måttfullhet (metron) som han finner vara en sällsynt kvalitet i litteraturhistorien.

De forskare som på ett ingående vis har studerat Vilhelm Ekelunds översättningar - jag tänker i första hand på Claes Schaar och Tobias Dahlkvist - betonar hur fritt översättaren förhåller sig till originalet och att det rör sig mer om kreativa tolkningar än om trogna översättningar av källtexterna. Schaar (1990: 22) kallar det för en "fri och subjektiv" översättningsmetod, där Ekelunds "egen profil avtecknar sig med stor tydlighet”. Även Dahlkvist (2010b: 6) är inne på samma tankespår då han skriver om hur Ekelund "omtolkar Leopardi" och hur han "åstadkommer en Leopardi som är mer lik honom själv". Ekelund ansåg sig uppenbarligen ha all rätt att i sitt översättningsarbete frigöra sig från källtexterna. Till sin vän K. A. Svensson ska han ha uttryckt åsikten att översättningar "huvudsakligen [bör] betraktas som produkter av översättarens personlighet" (Svensson, 1958: 50).

Från att kort ha uppehållit mig vid författarens biografi och vid de översättningar som han står bakom, ska jag i följande avdelning behandla den, enligt

17 Till skillnad från Baudelaire tillhörde han de författare från den romanska kultursfären som Ekelund förhåller sig vördnadsfullt beundrande till i de tidiga prosatexterna (jfr Aronsson, 2009: 89-90).

18 Se t. ex. Lindqvist (1966: 266) och Schaar (1990: 11). 
min uppfattning, viktigaste arenan för Vilhelm Ekelunds interkulturella möten - nämligen hans originaltexter.

\section{Interkulturalitet i det egna verket}

Vilhelm Ekelunds författarskap kan till stor del ses som ett samtal mellan honom själv och ett antal föregångare och själsfränder inom världslitteraturen. Denna ständigt pågående dialog bottnade i ett ingående studium av författarskap från de antika grekiska och romerska kultursfärerna. Det fanns även många tysk-, fransk-, italiensk- och engelskspråkiga skapare vars verk han med stort intresse studerade.

Man bör i det här sammanhanget lägga på minnet att för Vilhelm Ekelund var "studium" ett centralt, för att inte säga livsviktigt, begrepp. Det kopplas i hans texter ofta samman med positivt laddade termer som till exempel "frihet", "entusiasm" och "äventyr". I den postuma aforismsamlingen Nya vakten (1953: 20) skriver han exempelvis: "Allt hvad skola, allt hvad studium heter, har för mig samlat sig kring detta kapitala thema: andens frihet." Redan i Veri similia II (1916: 127) reflekterar han över begreppet, och kopplar samman det med idén om "möte":

Det bästa man kan vinna af studier är icke kunskaper, men enthusiasm.

Att lära känna stora personligheters sätt att ha umgänge med böcker är säkert en af de mest gifvande punkter man kan rikta sig på i bildningens historia. Där mötas andarna, där är lifvet starkt, och det helas innersta linje att se.

Citatet kan länkas till några anteckningar som Ekelundexperten Nils Gösta Valdén daterar till 1920-talet, och som postumt publicerats i Hemkomst och flykt (1972: 25 och 27). Där nämner Ekelund att studium för honom är ett "lifsgenomgripande äfventyr" och skriver även följande: "'Studium' -: endast såsom möte."19

Några sena aforismer ur Atticism - humanism bör också anföras, då de bidrar med ledtrådar till vad Vilhelm Ekelund själv åsyftade när han skrev om studier och bildningssträvan. Han hade ett i allra högsta grad produktivt förhållande till de stora föregångarna, och tycks mena att människans existentiella ensamhet bäst bekämpas i deras sällskap: "Tomma studier, tomma namn ha aldrig existerat för mig. Allt var umgängestörst, ensamhetsfruktan - blod-törst.” (Atticism - humanism, 1943: 169.) För Ekelund innebär alltså studier ett djupt förtroligt och sinnligt förhållande till förebilderna, och han använder sig i detta sammanhang av andning som metafor: "Hvad det var, hos de stora tänkarne

19 Ekelund stryker själv under ordet möte, och ger det därmed ökad emfas. 
jag ville? - Trodde jag mig få veta något?/Jag ville andas hos dem.” (Atticism humanism, 2:a uppl. med tillägg, 1946: 171. ${ }^{20}$

Studier och bildningssträvan var således en naturlig, och livsnödvändig, väg för Vilhelm Ekelund. Nils Gösta Valdén (1972: 5) påpekar att Ekelund läste andras verk "främst som medel till självkännedom" och mycket av det han skriver om sina förebilder är enligt Valdén i själva verket "maskerad bekännelse". ${ }^{21}$ Det ligger troligtvis en stor del sanning i ett sådant påstående, för Ekelunds framställningar av de författarskap som intresserar honom är som nämnts ovan ofta både självständiga och originella. ${ }^{22}$ Sannolikt beror det till stor del på att syftet med studierna är så specifikt, och av så stor vikt. Det handlar, som han själv skriver, om "blod-törst" och om att bekämpa människans "ensamhetsfruktan”. Det gör också att begreppet "möte" - som återfinns i denna artikels rubrik - är osedvanligt träffande när det gäller Vilhelm Ekelunds förhållande till litteratur. I hans läsning av andra författares texter är det verkligen frågan om ett kreativt möte mellan två skapande människor, mellan två sensibiliteter. När han skriver om en annan konstnärs liv och verk är det alltid resultatet av en fascination som går på djupet, och som i vissa fall närmast gränsar till besatthet.

Det faktum att Ekelund studerade andra författare som medel till självkännedom, som Valdén uttrycker det, är ofta lätt att läsa in mellan raderna i hans texter. I de postuma dagboks- och arbetsanteckningarna behöver man ibland inte ens göra det, eftersom det hela där är explicit uttryckt. Se exempelvis följande utdrag som behandlar Ekelunds förhållande till Emerson:

Trots [Emersons] stora öfverlägsenhet har jag ofta hos honom på ett egendomligt sätt tyckt mig igenkänna det bästa i mina egna möjligheter, och det föreföll mig då som vore han den man jag borde taga till lärare och mönster för mitt lif, min tanke. (Hemkomst och flykt, 1972: 57.)

20 Jfr också Per Erik Ljung som i sin avhandling (1980: 184) konstaterar att det i Vilhelm Ekelunds förhållande till heroerna "handlar om levda relationer" och att det finns en "märklig fysisk närhet i Ekelunds läsning”.

21 Se även Valdén (1974: 5): "Praktiskt taget allt som Vilhelm Ekelund skrev är bekännelse, öppen eller förklädd."

22 Denna aspekt av Vilhelm Ekelunds egenart, hans "läskonst”, uppmärksammades så tidigt som på 1940-talet i en monografi av K. A. Svensson. Denne hävdar bl.a. att Ekelund ständigt lyckas finna "helt andra kvaliteter" hos de författare han behandlar "än vad om dem vittnas i 'litteraturhistorien'." (Svensson, 1946: 71.) Han citerar i detta sammanhang Axel Forsström som angående Ekelunds läsning av Horatius har skrivit: "Ekelund har ur den Horatianska dikten arbetat fram livsvärden som ingen annan svensk läsare av skalden. När man läser hans aforismer över Horatius, kan man ibland tycka, att de flesta andra av dennes läsare hållit sig till utanverken och E. ensam under kärleksfullt studium trängt in till det innersta av hans väsen” (Ibid.: 70). 
Även i många av de texter som Vilhelm Ekelund själv redigerade för utgivning är han själv som läsare mycket närvarande. Det finns till exempel ingen anledning att tvivla på att den entusiastiska berättarrösten i följande exempel skulle tillhöra någon annan än Ekelund själv:

[...] en sådan diktare [som Leopardi] är ett stycke brinnande lif kastadt in i ens själ, reellare än allt hvad det reella lifvet är i stånd att skänka. - Och lifvet blir meningsfullt, högt, stilla. Som en natt på hafvet under stjärnorna. (Antikt ideal, 1909: 123.)

Man kallar Schopenhauer bitter. Jag fann honom mjuk som blommor, mild som morfin; försökte ofta att blifva honom otrogen, men lyckades aldrig. (Nordiskt och klassiskt, 1914: 5.)

Man måste - om i sin egen tid eller någon annan, det är likgiltigt - hafva mött den man, hvars öga man aldrig kan - icke får kunna vilja - undandraga sig. För mig var, i lyckliga dagar, Goethe denna blick och detta öga. (Lyra och Hades, 1930: 163.)

Ekelund når ofta en sällsynt förtrolighet med de tänkare som han fastnar för. I ett speciellt benådat ögonblick, skapat av morfininjektioner i samband med en allvarlig lungsjukdom under tidigt 1910-tal, tänker han på Platon och Emerson "med en intimitet som om de begge två vore mina personliga vänner, beskyddare och hjälpare." (Hemkomst och flykt, 1972: 46.) Om den tyske filosofen och socialdemokraten Ferdinand Lassalle säger han i en annan anteckning: "De tider jag lefvat med honom räknar jag till mina allra bästa. Aldrig har jag haft starkare hopp än då.” (Ibid.: 43.) Formuleringen i det sistnämnda citatet är talande för författarens inställning. Ekelund skriver inte att han läst eller ens studerat Lassalle, utan att han "lefvat med honom" - vilket naturligtvis indikerar en betydligt djupare och intimare relation än vad åtminstone det förstnämnda verbet hade gjort. ${ }^{23}$

I det följande kommer vi att se närmare på de stora förebildernas ursprung. Jag har grupperat dessa individer utifrån den nationalitet eller annan härkomst som anges i Andar i den Ekelundska sfären (1989), och kan på så vis presentera kvantitativa data över vilka kultursfärer som dominerar i Vilhelm Ekelunds författarskap.

\section{De stora andarna - varifrån kommer de?}

Den ovannämnda skriften Andar i den Ekelundska sfären (1989) har en deskriptiv undertitel som lyder: Personregister till Vilhelm Ekelunds skrifter. Den utgör

23 Om det någonsin funnits en författare på svenska språket som varit lyhörd för ords valörer och nyanser så är det Ekelund. Det finns därför ingen anledning att tro att ordvalet i det här fallet skulle vara oväsentligt för honom. För övrigt begagnar han sig av uttrycket även i en annan anteckning, där han skriver att han under en tid "lefde med Comte och Swedenborg" (Hemkomst och flykt, 1972: 84). 
en bearbetning och vidareutveckling av tidigare existerande förteckningar som funnits i stencilerad form sedan sextiotalet. Enligt baksidestexten omfattar registret "över tusen namn med biografiska uppgifter". Varje "ande" som Ekelund nämner i sina texter ges här en kortfattad presentation av typen "fransk filosof", "svensk författare", "grekisk historieskrivare", för att nämna några exempel. I samband med den här studien har jag gått igenom och sorterat de 1069 personer som figurerar i registret utifrån den nationalitet som anges för varje individ, och fått fram följande resultat:

Tabell 1: Andar i den Ekelundska sfären sorterade utifrån nationalitet

\begin{tabular}{lcc}
\hline $\begin{array}{l}\text { Nationalitet } \\
\text { (eller annan härkomst) }\end{array}$ & Antal individer & $\begin{array}{c}\text { Procent av totala } \\
\text { antalet individer }\end{array}$ \\
\hline Svensk & 250 & 23,4 \\
Tysk & 221 & 20,7 \\
Grekisk & 108 & 10,1 \\
Fransk & 98 & 9,2 \\
Romersk & 58 & 5,4 \\
Engelsk & 57 & 5,3 \\
Italiensk & 40 & 3,7 \\
Dansk & 35 & 3,3 \\
Rysk & 26 & 2,4 \\
Finländsk & 22 & 2,1 \\
Amerikansk & 20 & 1,9 \\
Norsk & 14 & 1,3 \\
Österrikisk & 12 & 1,1 \\
Schweizisk & 11 & 1,0 \\
Skotsk & 10 & 0,9 \\
Persisk & 8 & 0,7 \\
Holländsk, Nederländsk & 8 & 0,7 \\
Indisk & 7 & 0,6 \\
Arabisk & 6 & 0,6 \\
Spansk & 5 & 0,5 \\
Kinesisk & 5 & 0,5 \\
Judisk & 5 & 0,5 \\
Belgisk, Flamländsk & 5 & 0,5 \\
\hline Övriga ${ }^{24}$ & 569 & 3,5 \\
Summa & &
\end{tabular}

24 I gruppen "Övriga” inkluderas alla nationaliteter med färre än fem individer representerade: turkisk, makedonsk, irländsk, ungersk, tjeckisk, japansk, portugisisk, polsk, isländsk samt gruppen "oklassificerade" (vilken inbegriper sådana "andar" som i registret presenteras som t. ex. "nordisk", "germansk", "provençalsk", "fornvästnordisk", eller dylikt). 
Av tabellen framgår att hemlandet Sverige (med sina 250 individer) toppar listan över personer omnämnda i Ekelunds skrifter. Men det är värt att notera att siffran endast motsvarar $23,4 \%$ av det totala antalet, vilket naturligtvis innebär att lite fler än tre av fyra individer som nämns i hans verk är av utländsk härkomst. ${ }^{25}$ Tätt efter gruppen svenskar följer "andar” av tysk härkomst (20,7\%) och andra centrala kultursfärer som utkristalliserar sig i genomgången är som synes den grekiska $(10,1 \%)$, franska $(9,2 \%)$, romerska $(5,4 \%)$ och den engelska (5,3\%). Över 20 individer (eller 2,0\% av det totala antalet personer) har även nationaliteter som den italienska, danska, ryska och finländska. Sammanställningen ovan visar vilken bredd Ekelund uppvisade i sina studier. Han var inte ensidigt inriktad på en specifik kultursfär, utan läste både brett och fördomsfritt. Möjligen kan man i tabell 1 tolka in en viss eurocentrism, men det är i så fall knappast förvånande med tanke på Ekelunds klassicistiska bildningsgång. Då är det kanske mer överraskande att finna sådana kultursfärer som den persiska, indiska, arabiska, kinesiska och judiska representerade med fem eller fler individer vardera.

Tabell 1 konfirmerar också det som Vilhelm Ekelund skrev i en tidigare citerad anteckning om att "tyskt väsen jämte Hellas" blivit hans "lyckligaste upplefvelse" (Hemkomst och flykt, 1972: 42). Av tabellen framgår att dessa kulturområden också dominerar i verket, i det att tyska och grekiska skapare är oftast förekommande av de utländska individer som omnämns i Ekelunds skrifter.

\section{De stora andarna - vilka är de?}

Vilka är de då - Vilhelm Ekelunds litterära samtalspartner? Ja, ett antal namn har redan figurerat i denna artikel, exempelvis i citat eller när jag har diskuterat Ekelunds översättningar, och i tabell 2 nedan ges en mer systematisk översikt. Det rör sig här om en egen sammanställning av uppgifter framräknade ur frekvensordlistorna i Konkordans till Vilhelm Ekelunds skrifter (bd 4, 2000: 57296016).

25 Det relativt höga antalet svenskar som förekommer i Andar i den Ekelundska sfären (1989) kan dessutom ge en något överdriven bild av hemnationens betydelse. Detta eftersom också de två volymer av Ekelunds brevkorrespondens som publicerats ingår i registret. En person som aldrig omnämns i det egentliga litterära verket, utan endast figurerar i ett av hans brev, får då samma tyngd i min sammanställning som en litterär förebild som verkligen sysselsatt Ekelunds tankar under lång tid och som därför ofta figurerar i de texter som författaren själv redigerade för utgivning. Man kan anta att många individer av den förstnämnda kategorin är just svenskar, och att landet därmed kan vara något överrepresenterat i statistiken. 
Tabell 2: De 30 oftast förekommande individerna i Vilhelm Ekelunds verk

\begin{tabular}{|c|c|c|}
\hline Namn & $\begin{array}{l}\text { Nationalitet } \\
\text { (eller annan } \\
\text { härkomst) }\end{array}$ & $\begin{array}{l}\text { Antalet träffar i Konkordans } \\
\text { till Vilhelm Ekelunds skrifter } \\
(2000)^{27}\end{array}$ \\
\hline 1. Goethe, Johann Wolfgang von (1749-1832) & Tysk & $1204+139=1343$ \\
\hline 2. Nietzsche, Friedrich (1844-1900) & Tysk & $900+85=985$ \\
\hline 3. Platon (427-347) & Grekisk & $394+109=503$ \\
\hline 4. Emerson, Ralph Waldo (1803-1882) & Amerikansk & $441+26=467$ \\
\hline 5. Tegnér, Esaias (1782-1846) & Svensk & $258+49=307$ \\
\hline 6. Ekelund, Vilhelm (1880-1949) & Svensk & $299+0=299$ \\
\hline 7. Swedenborg, Emanuel (1688-1772) & Svensk & $212+45=257$ \\
\hline 8. Schopenhauer, Arthur (1788-1860) & Tysk & $228+23=251$ \\
\hline 9. Rousseau, Jean-Jacques (1712-1778) & Fransk & $169+79=248$ \\
\hline 10. Strindberg, August (1849-1912) & Svensk & $232+10=242$ \\
\hline 11. Leopardi, Giacomo (1798-1837) & Italiensk & $219+11=230$ \\
\hline 12. Pindaros (omkr. 518-438) & Grekisk & $142+87=229$ \\
\hline 13. Platen, August von (1796-1835) & Tysk & $196+6=202$ \\
\hline 14. Herakleitos (omkr. 540-480) & Grekisk & $112+81=193$ \\
\hline 15. Epikuros (341-270) & Grekisk & $93+96=189$ \\
\hline 16. Carlyle, Thomas (1795-1881) & Skotsk & $172+4=176$ \\
\hline 17. Shakespeare, William (1564-1616) & Engelsk & $130+45=175$ \\
\hline 18. Lassalle, Ferdinand (1825-1864) & Tysk & $161+7=168$ \\
\hline 19. Spinoza, Baruch (1632-1677) & Judisk & $147+20=167$ \\
\hline 20. Horatius $(65-8)$ & Romersk & $139+25=164$ \\
\hline 21. Lessing, Gotthold Ephraim (1729-1781) & Tysk & $141+22=163$ \\
\hline 22. Dostojevskij, Fjodor (1821-1881) & Rysk & $153+9=162$ \\
\hline 23. Sokrates (470-399) & Grekisk & $123+36=159$ \\
\hline 24. Hansson, Ola (1860-1925) & Svensk & $150+3=153$ \\
\hline 25. Plutarchos (46-120) & Grekisk & $55+92=147$ \\
\hline 26. Alighieri, Dante (1265-1321) & Italiensk & $115+16=131$ \\
\hline 27. Rydberg, Viktor (1828-1895) & Svensk & $113+14=127$ \\
\hline 28. Hölderlin, Friedrich (1770-1843) & Tysk & $122+3=125$ \\
\hline 29. Kierkegaard, Søren (1813-1855) & Dansk & $115+10=125$ \\
\hline 30. Ibsen, Henrik (1828-1906) & Norsk & $109+12=121$ \\
\hline
\end{tabular}

26 Uppgifterna om "nationalitet" har, tillsammans med de biografiska noteringarna om födelse- och dödsår, tagits ur Andar i den Ekelundska sfären (1989).

27 Det första talet i kolumnen anger antalet träffar på personernas egennamn (i första fallet Goethe) plus genitivformen (Goethes) enligt Konkordans till Vilhelm Ekelunds skrifter (2000). Det andra anger övriga former och sammansättningar - för Johann Wolfgang von Goethe rör det sig t. ex. om ord som goethesk, goetheartad, goetheförbindelsen, goethe-aristoteliska, goethe-ord, goethe-upplefvelse och goethe-versen. Det tredje talet, markerat med fet stil, ger totalsumman. 
Man kan konstatera att två tyskspråkiga författare står i en klass för sig, nämligen Goethe och Nietzsche. Att just dessa två skriftställare toppar listan kommer knappast som någon överraskning för den läsare som någon gång öppnat en prosavolym av Vilhelm Ekelund. Det rör sig nämligen om skapare vars tankar sysselsatte honom under hela hans essäistiska och aforistiska författarskap. Därför spelar det i stort sett ingen roll vilken skrift man slår upp, man kommer med stor sannolikhet finna att såväl Goethes som Nietzsches namn är flitigt förekommande i texten.

Vi noterar också att samtliga personer som dyker upp i listan är författare eller filosofer, och att det krävs så många som 121 omnämnanden för att slå sig in på listan över de 30 oftast förekommande namnen i Vilhelm Ekelunds verk. Det vittnar om hur omfattande diskussioner om litteratur och filosofi som faktiskt förs i dessa skrifter - eller, om man så vill, om hur många interkulturella möten med andra författare som uppstår där. Naturligtvis finns det åtskilliga skapare som omnämns färre än 121 gånger, och som följaktligen inte kvalificerar sig för ovanstående topplista.

Att Ekelunds eget namn dyker upp på sjätte plats i tabellen, med så många som 299 träffar, betyder inte att han nämner sig själv osedvanligt ofta i sitt verk. Istället ser vi här ett resultat av att författarens brev (utgivna i två volymer) ingår i konkordansen, brev som han alltså i många fall undertecknade med sitt efternamn. I det följande kommer jag att bortse från dessa träffar, eftersom de är irrelevanta ur ett interkulturalitetsperspektiv.

Av de oftast förekommande författarna är en majoritet (24 av 29) utländska, och merparten av dem kan räknas till världslitteraturens kanoniska namn. Det gör att inledningens resonemang om Ekelunds skrifter som en interkulturell mötesplats för honom själv och de främsta inom världslitteraturen synes välmotiverad. De stora Ekelundska kultursfärerna, hans "lyckligaste upplefvelse", från tabell 1 finns även här väl representerade: den tyska genom sammanlagt sju namn (de stora heroerna Goethe och Nietzsche förstås, men också Schopenhauer, Platen, Lassalle, Lessing och Hölderlin) och den grekiska genom sex representanter (Platon, Pindaros, Herakleitos, Epikuros, Sokrates och Plutarchos). Även de övriga dominerande kultursfärerna från tabell 1 återkommer här: den romerska (Horatius), engelskspråkiga (Emerson, Carlyle och Shakespeare), franskspråkiga (Rousseau) och italienska (Leopardi och Dante).

De fem svenska skapare som når in på topplistan förtjänar också en kort presentation. Strindberg är en författare av internationellt renommé och hans närvaro förvånar därför knappast. Även Esaias Tegnér tillhör den svenska nationallitteraturens giganter. Emanuel Swedenborg presenteras i Andar i den Ekelundska sfären (1989: 68) som "svensk naturforskare och mystiker", och eftersom jag har följt klassificeringen från detta verk räknas han även i min 
sammanställning till de svenska skaparna. Man kan emellertid hävda att Swedenborgs intellektuella gärning är mer europeisk än specifikt svensk till sin natur. Eftersom han skrev alla sina viktiga verk på latin, och lästes av Ekelund på detta språk, är det tveksamt om hans namn i kulturhistoriskt hänseende egentligen bör föras till gruppen svenskar. Vad gäller Ola Hansson så tillhörde han pionjärerna inom det som ibland kallas för den skånska skolan i svensk poesi, och han var periodvis en viktig inspirationskälla för Vilhelm Ekelund. Även Viktor Rydberg når som synes in på topplistan, vilket indikerar att Ekelund under lång tid hade ett produktivt förhållande till honom, och att denne sysselsatte Ekelunds tankar på ett genomgripande vis.

Det kan även vara på sin plats att nämna att samtliga författare är av äldre generationer än Ekelund. De grekiska och romerska namnen (sju stycken allt som allt) tillhör förstås det klassiska västerländska kulturarvet, och många av de 22 "moderna" författare som figurerar i tabell 2 kan också sägas ha varit en del av den kanoniserade litteraturhistorien redan under Vilhelm Ekelunds epok. Det var väl egentligen bara August Strindberg, Ola Hansson och, i viss mån, Henrik Ibsen som fortfarande var aktiva på den litterära scenen när Ekelund formades som läsare och författare. ${ }^{28}$

Efter de tidiga diktaråren, då Ekelund lät sig inspireras av vissa modernistiska och samtida poeter, förhöll han sig mestadels avståndstagande till hela sin litterära samtid. Antikvurmaren Vilhelm Ekelund saknade i det stora hela intresse för nittonhundratalets litteratur. Han var en typisk "ancien” i den bemärkelsen att det klassiska kulturarvet för honom framstod som oöverträffat. Han beundrade de tyska nyklassicisterna och visade välvillig förståelse även för andra författare vars skapande var väl förankrat i antiken. Men hans sympati hade en gräns: så långt som in i nittonhundratalet sträckte den sig aldrig:

En författare, om han förstår sin fördel, undviker konsekvent att läsa moderna författare. Hvarför dricka ljumt grums ur landsvägspöl, när det finns källor i skogen med fin kall dryck! (Böcker och vandringar, 2:a uppl. 1923: 125.)29

28 Friedrich Nietzsche avslutade sitt författarskap när Vilhelm Ekelund var i tidiga tonåren, men den postuma och av Ekelund länge emotsedda självbiografin Ecce homo gavs ut 1908, vilket också omnämns i essän ”Die eiserne Lerche” i Tyska utsikter (1913).

29 Se också Olle Holmberg (1963: 135), Nils Gösta Valdén (1971: 151) samt Walter Klein (1950) som alla behandlar Ekelunds avståndstagande attityd gentemot sin samtids litteratur. Den sistnämnde var för övrigt personligt bekant med Vilhelm Ekelund och förmedlade efter dennes död följande intryck: ”Ekelunds attityd mot flertalet litterära samtida var, så länge jag känt honom, med ett mycket blitt uttryck sträv; jag skulle snarare vilja beteckna den som fientlig, misstänksamt defensiv och ej sällan aggressiv” (Klein, 1950: 71). 
Talande är förmodligen att Ekelund, när han i Väst-Östligt översatte ett antal aforismer av den tyske författaren Jean Paul, valde att på första sidan placera följande tänkespråk:

Stora män verka sällan gemensamt i rummet; men i tiderna sträcka de händerna mot hvarandra alla - ur andevärlden - endräkteligen förenade till samma byggnads verk. (Väst-östligt, 1925: 7.)

Citatet visar hur Ekelund såg på frågan om den stora litteraturens och de stora författarnas uppgift och roll. De bidrar med byggstenar till en och samma andes hus. Och det är detta byggnadsverk som Ekelund under hela sin levnad vände och vred på, skärskådade och analyserade, och som han genom sina egna skrifter bidrog till att bygga ut och förstärka.

Noteras bör att den eurocentrism som kunde urskiljas i tabell 1 här syns ännu tydligare, eftersom samtliga 29 namn i listan ovan tillhör den västerländska kulturhistorien. Vilhelm Ekelund nämner förvisso ett antal persiska, indiska, arabiska och kinesiska författare i sina skrifter, men utifrån "topplistan” i tabell 2 kan man konstatera att intresset för utomeuropeiska skapare likväl framstår som relativt perifert.

Samtliga 29 författare är också män, inte ett enda kvinnligt namn bryter upp den manliga hegemonin. Den västerländska litterära kanon har förstås av tradition i mångt och mycket varit dominerad av män - och mer så på Vilhelm Ekelunds tid än idag, då kvinnliga författarskap skrivs fram i ljuset och uppmärksammas på ett sätt som inte varit fallet tidigare. Men redan under Ekelunds livstid hade ju faktiskt ett begränsat antal kvinnor lyckats slå sig igenom den patriarkala muren och ta plats i den litterära kanon. Det kan därför vara värt att notera avsaknaden av sådana namn i listan ovan. Där finns inte någon Madame de La Fayette eller George Sand, ingen Brontë-syster, Jane Austen eller Emelie Flygare-Carlén. ${ }^{30}$ Utifrån det statistiska råmaterial som ligger till grund för föreliggande studie kan endast en slutsats dras: den litterära parnass som Ekelund bygger upp i sina skrifter är en exklusivt manlig, vit och västerländskt dominerad värld.

30 Ekelund använder ju också påfallande ofta adjektiven "kvinnlig” och "feminin" som skällsord i sina texter, vilket även det indikerar att han inte var speciellt positivt inställd till kvinnliga författarskap. Faktum är att bland de 60 oftast förekommande personnamnen - vilket är så långt ner i frekvensordlistan till Konkordans till Vilhelm Ekelunds skrifter, bd 4 (2000: 58736016) som jag har räknat - förekommer det inte ett enda kvinnligt namn. För att nyansera bilden en aning skall dock nämnas att Ekelund tidvis faktiskt hade ett produktivt förhållande till vissa kvinnliga författare - Sapfo och Victoria Benedictsson är två sådana exempel - även om detta faktum förblir osynligt i min kvantitativt inriktade studie. 


\section{Nordiskt och klassiskt}

Ett annat exempel på interkulturalitet i Vilhelm Ekelunds tankevärld är det viktiga motivkomplexet "nordiskt och klassiskt". Begreppet är förstås mest känt som titel på en aforismsamling publicerad 1914, men som Sven Lindqvist har visat i sin avhandling (1966: 297-366) figurerar detta motiv såväl i det tidigare som i det senare författarskapet. ${ }^{31}$ I Ekelunds skrifter behandlas motivet på så vis att författaren ställer nordiska författarskap, kultursfärer, "nationalkaraktärer” m. m. mot de klassiska och undersöker dem komparativt. Han jämför och kontrasterar dem, hittar beröringspunkter och skiljelinjer - allt på sitt eget oefterhärmliga vis. Att på ett rättvisande sätt illustrera hur Vilhelm Ekelund utvecklar motivkomplexet ifråga skulle här föra alltför långt. Intresserade läsare hänvisas till Nordiskt och klassiskt och till Lindqvists avhandling från 1966 som behandlar just denna aspekt av Ekelunds skrivande. Här skall jag endast ge ett kort exempel. För att illustrera hur motivet framträder också i det övriga författarskapet väljer jag att återge ett utdrag ur Antikt ideal (1909: 100-101):

Tegnér är den ende svenske diktare som stått i djupt och personligt förhållande till antiken. Jämförd med hans friska kärfva och storartadt ljusa uppfattning - hur kvaf och feministisk ter sig inte en Viktor Rydbergs sentimentalt dekorativt-antikiserande tendens! Att Tegnér förnam antiken i botten, det bevisar ingenting lifligare än hans hat till den tyska och svenska romantiken. Ty här varsnade han en princip som var antikens på det djupaste fientlig: klemandet med det "öfversinnliga”, den gudsnådliga sirapsfromheten inför "lifvets under", nermördandet af den friska hårda viljan, äfventyrslusten, strängheten mot sig själf, tapperheten. Tegnérs sångmö har skarpa blixtrande ögon. Det är hans egna ord, och jag tänker mig gärna att de tillkommit genom någon hemlig eller medveten association med den romerske historieskrifvaren Tacitus' ord om germanernas ögon: oculi truces, hvilket betyder detsamma. Tegnér var en stor Tacitus-entusiast. Hvad tänkte sig väl Tegnér, när han siar om den sångens hjälte som en gång komma skall för Norden? Var det inte det djupast och vekast nordiska strålande upp i spänstigt förbund med antikens ande!

Som synes låter Vilhelm Ekelund här två svenska diktare från tabell 2 (Rydberg och Tegnér) möta det klassiska kulturarvet i form av Tacitus. Tegnérs förhållande till antiken och den romerske historieskrivaren vinner nåd, medan Viktor Rydbergs förringas med för Ekelundläsaren välkända invektiv som "sentimen-

31 Lindqvist (1966: 300) hittar exempel så tidigt som i diktsamlingen Dithyramber i aftonglans från 1906 och avslutar kapitlet med att konstatera att "i någon form återkommer motivet nordiskt och klassiskt i nästan alla hans böcker, inte minst de posthuma.” (Ibid.: 365-366.) Essän "Nordiskt Arkadien" (tryckt i Antikt ideal, 1909: 153-158) förtjänar nog speciellt att omnämnas i detta sammanhang, eftersom den till stora delar tar upp samma motiv som Nordiskt och klassiskt och därför kan sägas utgöra en sorts förstudie till det senare verket. 
tal" och "feministisk". Det framgår också tydligt av citatet vilka aspekter av antik kultur som Ekelund tar fasta på som ideal och ledstjärnor under det tidiga författarskapet på prosa: det är den "friska hårda viljan, äfventyrslusten, strängheten mot sig själf, tapperheten" som vid den här tiden i första hand fångar hans intresse.

\section{Titlar och citat}

I sin studie Seuils (1987: 54-97) ägnar Gérard Genette ett längre kapitel åt titelns betydelse för det litterära verket. Han skriver bland annat att titeln har åtskilligt fler mottagare (destinataires) än vad själva texten har. Detta eftersom texten är ett "läsobjekt" till skillnad från titeln som är ett "cirkulationsobjekt" eller, som han också uttrycker det, ett "samtalsämne". ${ }^{32}$ Eftersom titlarna således har en specifik funktion, och når fler människor än vad texterna gör, är det utifrån ett interkulturalitetsperspektiv intressant att titta närmare på de verk som givits ut med en titel på utländskt språk.

Av tabell 3 nedan framgår att tolv av Vilhelm Ekelunds utgivna skrifter bär en helt eller delvis utländsk titel. Man kan direkt notera att språken som används är de klassiska: i åtta fall rör det sig om latin och i fyra fall är det grekiska. $^{33}$

Tabell 3: Verk med helt eller delvis utländska titlar i Vilhelm Ekelunds författarskap

\begin{tabular}{lll}
\hline Verk och utgivningsår & Språk i titeln & Svensk översättning \\
\hline In Candidum (1905) & Latin & "Tillägnad Candidus" \\
Veri similia (1915) & Latin & "Sannolikheter" eller \\
& & "Det sannolika" \\
Veri similia II (1916) & Latin & Se ovan \\
Metron (1918) & Grekiska & "Mått” eller "versmått" \\
Elpidi (1939) & Grekiska & "Åt hoppet" \\
Concordia animi (1942) & Latin & "Själens endräkt" eller "själens \\
& & samstämmighet" \\
\hline
\end{tabular}

32 "Car, si le texte est un objet de lecture, le titre [...] est un objet de circulation - ou, si l'on préfère, un sujet de conversation." (Genette, 1987: 73.)

33 Jag koncentrerar mig här på sådana verk vars titel innehåller ett eller flera ord på utländska språk. Naturligtvis finns det även titlar som innehåller ord med utländskt ursprung, vilka är så pass "inarbetade" i det svenska språket att de får anses vara bekanta för en svensk läsare. Hades och atticism är exempel på sådana ord. Därutöver finns många helt svenskspråkiga titlar som indikerar ett intresse för de klassiska kultursfärerna. Grekisk bukett och Antikt ideal är två exempel på fenomenet. 
Tabell 3: Fortsättning

\begin{tabular}{lll}
\hline Verk och utgivningsår & Språk i titeln & Svensk översättning \\
\hline Plus salis - (1945) & Latin & "Hellre salt" eller "Mer smak" \\
Ars magna (1954) & Latin & "Stor konst" \\
Saltet och helichrysus (1956) & Svenska och grekiska & Helichrysus: "krypguld', eternell" \\
In silvis cum libro (1957) & Latin & "I skogarna med en bok" \\
Campus et dies (1963) & Latin & "Fältet och dagen" \\
Ur en scholaris' verkstad (1974) & Svenska och grekiska & $\begin{array}{l}\text { Scholaris: "Klassiskt bildad } \\
\end{array}$ \\
& & diktarkritiker" \\
\hline
\end{tabular}

Av listans tolv volymer utkom de sju första under författarens livstid, och ett rimligt antagande är att Ekelund själv står bakom titelvalet vad gäller dessa publikationer. Grekiska eller latinska titlar var nämligen inte något som hjälpte upp den redan från början magra försäljningen av Ekelunds skrifter, och det är därför osannolikt att en förläggare skulle ha insisterat på de valda namnen. ${ }^{35}$ För övriga fem titlar (1954-1974) står de forskare som för Vilhelm Ekelundsamfundets räkning har sammanställt och givit ut författarens efterlämnade material. Uppenbarligen har man varit mån om att verka i författarens anda, och inte sällan har man försett de postuma skrifterna med titlar på de klassiska språken. I spetsen för utgivningen av kvarlämnade manuskript har Ekelundexperten Nils Gösta Valdén länge stått. Valdén doktorerade 1961 på avhandlingen Grekiska termer hos Vilhelm Ekelund, och det är väl troligt att han med sin klassicistiska intresseinriktning har haft visst inflytande på valet av titlar för de postuma skrifterna. ${ }^{36}$

Vilhelm Ekelunds förkärlek för citat på utländska språk är något som frapperar varje läsare av hans verk. Citat på originalspråk förekommer redan i de

34 Översättningarna av titlarna har hämtats från följande källor: Jonas Ellerström, 2004b: 269; Algot Werin, 1961: 231 resp. Nils Gösta Valdén, 1999: xxi; Werin, 1961: 272; Carl-Erik af Geijerstam, 1963: 9; ibid.: 18; Valdén, 1965: 114 resp. Lennart Bruce, 1993: 218; Sven Lindqvist, 1961: 86; ibid.: 88; Valdén, 1965: 74; ibid.: 74; Valdén, 1974: 6.

35 Jonas Ellerström (2004b: 269) skriver exempelvis att Ekelund "fick igenom" titeln In Candidum "trots förlagets betänkligheter". När sedan Vilhelm Ekelundsamfundet bildades i mitten av trettiotalet för att ta över utgivningen av hans böcker kunde dess ordförande, advokaten Walter Klein, bara defaitistiskt konstatera att författaren framhärdade i sina val av titlar som var obegripliga för en stor del av den läsande allmänheten. Efter den ytterst dåliga försäljningen av Elpidi följde ett nytt verk, om vilket K. A. Svensson (1958: 323) har följande anekdot att berätta: "Jag hade i brev till E. omtalat, att när jag för Klein nämnde namnet på den nya boken, Concordia animi, suckade K. djupt och utropade: 'Ack, det är en saga!”'

36 Valdén visade för övrigt själv ett intresse för Ekelunds val av titlar, vilket framgår av essän ”Om Vilhelm Ekelunds boktitlar" publicerad i Inledning till Vilhelm Ekelund (1965: 77-116). 
tidiga prosaskrifterna, och Pierre Naert (1949: 123) har visat att dessa blir allt talrikare i det sena författarskapet, framför allt från och med Det andra ljuset (1935). Naert konstaterar att tyskspråkiga citat är oftast förekommande, och av hans tabell (1949: 120-121) kan man utläsa att proportionerna är följande: de tyskspråkiga citaten står för 35,6\% av det totala antalet utländska citat, latinska står för 29,7\%, grekiska 18,0\%,37 engelska 7,3\%, franska 6,3\% och italienska 3,1\%. Tyskland dominerar alltså inte bara vad gäller antalet utländska "andar” som nämns i Ekelunds skrifter (tabell 1), samt antalet individer som tillhör de 30 oftast förekommande personerna i detta verk (tabell 2), utan tyska är också det språk som oftast figurerar i de citat som är ett så karakteristiskt inslag i Ekelunds prosatexter. Näst vanligast är enligt Naert latinska citat, vilket kan synas något förvånande med tanke på att den romerska kultursfären "bara" kommer på femte plats i min sammanställning ovan (tabell 1) och att enbart en romersk författare - Horatius - återfinns i listan över de 30 oftast förekommande namnen i Vilhelm Ekelunds verk (tabell 2). En rimlig slutsats blir då att även om Ekelund omnämner färre romerska individer i sina texter än vad han nämner grekiska och franska skapare, så citerar han dem flitigare. En annan aspekt som kan vara av viss betydelse i sammanhanget är att det latinska språket används av fler än de romerska författarna, då det under många århundraden innehade en särställning som västerlandets stora kulturbärande lärdomsspråk. Jag har redan nämnt Swedenborg som ett exempel på en tänkare som uttrycker sig på latin, trots att han inte kan sorteras in i gruppen "romerska" författare. Ett analogt fall finner man för övrigt i den holländsk-judiske filosofen Spinoza, som även han figurerar i ovanstående topplista.

De många utländska citaten i Vilhelm Ekelunds verk ställer naturligtvis stora krav på läsarens språkkunskaper och klassiska bildning, och bidrar på så vis till den aura av ogenomtränglighet som länge har svävat över detta författarskap. Den läsare som inte behärskar tyska, franska, latin och klassisk grekiska finner sig mången gång stå framför mer eller mindre obegripliga passager, vilket naturligtvis kan upplevas som frustrerande. Läsaren upptäcker dock snart att många resonemang faktiskt går att förstå med hjälp av den omgivande kontexten. ${ }^{38}$ Ekelunds prosatexter, i synnerhet de senare aforismerna, är svårtolka-

37 Vad gäller de grekiska citaten skriver Naert (1949: 147) att translitterering - vilket i det här fallet står för grekiska citat återgivna med våra vanliga latinska tecken - är vanligast i det tidiga verket. Sedan jämnas förhållandet ut, och från och med Båge och lyra 1932 (1932) överväger citat med grekiska bokstäver (icke translitterering).

38 I de kommenterade nyutgåvor av Ekelunds prosaskrifter som Ellerströms förlag publicerat under 1990- och 2000-talen har Nils Gösta Valdén översatt många av citaten till svenska och därmed i stort sett eliminerat problemet vad gäller de återutgivna titlarna. 
de, det ska inte förringas. Men svårigheterna ligger enligt min mening lika mycket i författarens med tiden allt mer förtätade meningsbyggnad, och de nya och ibland oväntade betydelser som han lägger i till synes helt vanliga svenska ord, som till exempel "öga", "låghet", "gräns" och "musik".39

\section{Slutord}

I föreliggande artikel har jag försökt visa vilka interkulturella möten som uppstår i Vilhelm Ekelunds författarskap. Jag har kort diskuterat den interkulturalitet som kan skönjas i Ekelunds biografi och i de översättningar av utländska författare som han står bakom, för att sedan koncentrera studien till de interkulturella möten som uppkommer i det egentliga författarskapet, det vill säga i hans egna originaltexter.

Alla Ekelundkännare vet förvisso redan att de tyska, grekiska, franska, romerska och engelska kultursfärerna - jämte den svenska - är av avgörande betydelse för Vilhelm Ekelunds författarskap. De vet också att Goethe, Nietzsche, Platon, Emerson och Tegnér är författare som ofta diskuteras i Ekelunds skrifter. Det nydanande med den här studien är att omfattningen av de interkulturella mötena framgår tydligt. Jag använder mig av ett statistiskt råmaterial för att presentera kvantitativa data över dessa författares och kultursfärers närvaro i verket. Därmed tydliggörs för första gången proportionerna dem emellan (se tabell 1 och 2 ovan). En kvantitativt inriktad undersökning ska naturligtvis endast ses som ett komplement till mer textnära litteraturvetenskaplig forskning. Det vore alltså förmätet att påstå att föreliggande artikel skulle ge en heltäckande bild av alla de interkulturella möten som uppstår i Ekelunds verk. Däremot ger den en övergripande bild av de viktigaste mötena - en bild baserad på ett tillförlitligt statistiskt källmaterial - och som fram till idag har saknats inom Ekelundforskningen. Med sitt fokus på numerärer och procentandelar fyller den alltså en

39 Det rör sig här om de Ekelundska "kryptologismer" som uppmärksammats av åtskilliga kommentatorer av detta författarskap. Tyvärr skulle det här föra alltför långt att söka redogöra för vilken roll dessa termer spelar i verket. Låt oss bara konstatera att "öga" ofta får stå för det renaste och djupaste hos en människa (se Naert, 1949: 311), att "låghet” så gott som alltid är ett positivt konnoterat substantiv använt i betydelsen anspråkslöshet och ödmjukhet (ibid.: 345-347), att "gräns" kan stå för exempelvis koncentration och återhållsamhet i känsla (ibid.: 334) - samt att "musik" nästan aldrig används om tonkonsten, utan istället får tillbaka sin ursprungliga grekiska betydelse av bildning och vitterhet (ibid.: 322). För en betydligt mer ingående diskussion om Ekelunds kryptologismer, se Naert (1949: 310-416). Även Lindqvist (1966: 284-296 samt 401-408) och Bruce (1993: 215-225) har i viss mån behandlat ämnet. 
lucka och den kompletterar, enligt mitt förmenande, på ett lämpligt vis de mer textcentrerade studier som under lång tid har bedrivits av Ekelundforskare i Sverige, varav vissa har omnämnts i denna artikels inledning.

Vilhelm Ekelunds prosatexter ser på ytan ofta ut som författarpsykologisk litteraturkritik - om än en ytterst självständig, och ibland självsvåldig, variant av litteraturkritik. Men i själva verket är det minst lika mycket frågan om essäer i levnadskonst, där de diskuterade författarnas och filosofernas tankar prövas och befinns värdefulla, alternativt förkastas, i Ekelunds jakt på ett hållbart modus vivendi. ${ }^{40}$ Även om han har skrivit mycket, och insiktsfullt, om svensk litteratur sökte han sig redan från början också till andra språk- och kultursfärer för sin bildning, och det förblev en konstant författarskapet igenom. I den postuma aforismsamlingen In silvis cum libro (1957: 24) uttrycker han exempelvis följande tanke:

Legitimare flykt gives icke, än flykten från dagsmisären, mikrologien, det nationella bildningsflinet -:

striden för de vidsträckta utsikterna!

Att en skapande människa på flykt undan det han upplever som "dagsmisären" och "det nationella bildningsflinet" i första hand väljer att sätta sig till bords med den kanoniska världslitteraturens giganter är inte svårt att förstå. Det var hos dessa heroer som Vilhelm Ekelund fann de "vidsträckta utsikter" som han behövde för sitt eget liv och sitt eget skapande. Därmed blir också termen interkulturellt möte ett så centralt begrepp i hans författarskap.

\section{Källor}

\section{Primärlitteratur}

Ekelund, Vilhelm 1922: Sak och sken. Stockholm.

Ekelund, Vilhelm 1922: På hafsstranden. Stockholm.

Ekelund, Vilhelm 1930: Lyra och Hades. Stockholm.

Ekelund, Vilhelm 1935: Det andra ljuset. Stockholm.

Ekelund, Vilhelm 1943: Atticism - humanism, Demokraten. Hälsingborg.

Ekelund, Vilhelm 1946: Atticism - humanism (andra upplagan med tillägg). Hälsingborg.

Ekelund, Vilhelm 1953: Nya vakten. Hälsingborg.

Ekelund, Vilhelm 1957: In silvis cum libro. Hälsingborg.

40 Jfr exempelvis Valdén (1971: 142) som slår fast: ”Emellertid sökte han inte bara en konst utan också en livskonst. Därmed blev hans studier pragmatiska." 
Ekelund, Vilhelm 1970: Brev 1917-1949. Red. av Nils Gösta Valdén \& Algot Werin. Lund. Ekelund, Vilhelm 1972: Hemkomst och flykt. Självbiografiska anteckningar. Lund.

Ekelund, Vilhelm 1983 [1909; 1912]: Antikt ideal. Båge och lyra. Lund.

Ekelund, Vilhelm 1984: Den ensammes stämningar. Artiklar och dikter 1898-1910. Lund.

Ekelund, Vilhelm 1991: Böcker och vandringar. Från studie-år i Tyskland (faksimiltryck av andra upplagan, innehållande Tyska utsikter). Lund.

Ekelund, Vilhelm 1999 [1914, 1915, 1916]: Nordiskt och klassiskt. Veri similia I-II. Lund.

Ekelund, Vilhelm 2004: Samlade dikter I. Stockholm.

Ekelund, Vilhelm 2005: Lefnadsstämning. Väst-östligt. Lund.

Ekelund, Vilhelm 2013: Oroligt blod. Berättelser och skisser. Lund.

\section{Sekundärlitteratur}

Andar i den Ekelundska sfären. Personregister till Vilhelm Ekelunds skrifter 1989. Lund.

Aronsson, Mattias 2009: "Vilhelm Ekelund och den fransk-italienska kultursfären. Några nedslag i de tidiga prosaverken - från Antikt ideal (1909) till Attiskt i fågelperspektiv (1919)”. In: Samlaren. Tidskrift för svensk litteraturvetenskaplig forskning 130. Uppsala. 85-101.

Bergquist, Lars 1999: "Swedenborg - Ekelund: porträtt med dubbelexponering”. In: Per Erik Ljung \& Helena Nilsson (red): Den största lyckan. En bok till Vilhelm Ekelund. Lund. 209-218.

Bruce, Lennart 1993: "Nyckelbegrepp i Vilhelm Ekelunds språk”. In: Vilhelm Ekelund. Det andra ljuset. Texter i urval och med inledning av Lennart Bruce. Stockholm/Stehag. 215225.

Dahlkvist, Tobias 2010a: Förtvivlans filosofi. Vilhelm Ekelund och mottagandet av Giacomo Leopardi i Skandinavien. Lund.

Dahlkvist, Tobias 2010b: "Vilhelm Ekelunds Leoparditolkningar". In: IASS 2010. Översättning - adaption, interpretation, transformation, 1-8. http://nile.lub.lu.se/ojs/index.php/ IASS2010/article/ view/5013/4455. (Konsulterad 2012-05-27.)

Ekman, Rolf 1951: Vilhelm Ekelund och Nietzsche. Lund.

Ekman, Rolf 1976: "Platon och platonism i Ekelunds prosaböcker". In: Ekelundstudier 191276. Lund. 138-148.

Ellerström, Jonas 2004a: "Kommentarer och ordförklaringar" In: Vilhelm Ekelund, Samlade dikter I. Stockholm. 239-288.

Ellerström, Jonas 2004b: "Kommentarer och ordförklaringar". In: Vilhelm Ekelund, Samlade dikter II. Stockholm. 269-345.

Elovson, Harald 1966: "Vilhelm Ekelund och Rousseau fram till 1920". In: Vetenskapssocieteten i Lund. Årsbok 1966. Lund. 1-75.

Elovson, Harald 1968: "Vilhelm Ekelund och Rousseau 1920-1949". In: Vetenskapssocieteten i Lund. Årsbok 1968. Lund. 3-105.

Geijerstam, Carl-Erik af 1963: Det personliga experimentet. Studier i Vilhelm Ekelunds aforismer. Stockholm.

Genette, Gérard 1987: Seuils. Paris.

Gilsenan Nordin, Irene, m. fl. (red.) 2013: Transcultural Identities in Contemporary Literature. Amsterdam. 
Hansson, Gunnar D. 2002: "Thorild - den ljusa stjärnan". In: Ingrid Schaar (red): Ett nytt språk. Essäer om ord och begrepp hos Vilhelm Ekelund. Stockholm. 55-64.

Holmberg, Olle 1963: "Tre uppsatser om Vilhelm Ekelund". In: Olle Holmberg, Skratt och allvar i svensk litteratur. Studier från fyra århundraden. Stockholm. 127-145.

Klein, Walter 1950: "Minnesbild av Vilhelm Ekelund". In: Forsström, Axel \& K. A. Svensson (red): En bok om Vilhelm Ekelund. Lund. 69-87.

Landquist, John (red.) 1946: Filosofiska mästerverken. Bd. VII, Kant och romantikens tyska tänkare. Stockholm.

Levande möte. Vilhelm Ekelunds Emersontolkningar. Med inledning och kommentar av Claes Schaar. 1990. Lund.

Lindqvist, Sven 1961: "Ordlista". In: Vilhelm Ekelund: Skoltal. Aforismer i urval av Sven Lindqvist. Stockholm. 86-91.

Lindqvist, Sven 1966: Dagbok och diktverk. En studie i Vilhelm Ekelunds Nordiskt och klassiskt. Stockholm.

Ljung, Per Erik 1980: Vilhelm Ekelund och den problematiska författarrollen. Lund.

Ljung, Per Erik 2009: Drömmar som förplikta. Om Vilhelm Ekelund och hans läsare. Lund.

Naert, Pierre 1949: Stilen $i$ Vilhelm Ekelunds essayer och aforismer. Med en inledning om stilistikens förutsättningar och arbetsmetoder. Lund.

Nationalencyklopedin. http://www.ne.se/

Schaar, Claes 1976: “Läkedomsformler; Vilhelm Ekelund och Dante”. In: Ekelundstudier 191276. Lund. 154-164.

Schaar, Claes 1990: "Inledning”. In: Levande möte. Vilhelm Ekelunds Emersontolkningar. Lund. 11-32.

Schaar, Ingrid (red) 2000: Konkordans till Vilhelm Ekelunds skrifter (bd 4). Lund.

Ståhl, Eva-Britta 1999: "Ekelund och Hölderlin". In: Ljung, Per Erik \& Helena Nilsson (red): Den största lyckan. En bok till Vilhelm Ekelund. Lund. 60-70.

Svensson, K. A. 1946: Vilhelm Ekelund. Moralisten - kulturkritikern. Stockholm.

Svensson, K. A. 1958: Vilhelm Ekelund i samtal och brev 1922-1949. Lund.

Valdén, Nils Gösta 1961: Grekiska termer hos Vilhelm Ekelund. Lund.

Valdén, Nils Gösta 1965: Inledning till Vilhelm Ekelund. Lund.

Valdén, Nils Gösta 1971: "Vilhelm Ekelund och världslitteraturen". In: Vetenskapssocieteten $i$ Lund. Årsbok 1971. Lund. 142-156.

Valdén, Nils Gösta 1972: "Förord". In: Vilhelm Ekelund: Hemkomst och flykt. Självbiografiska anteckningar. Lund. 5-7.

Valdén, Nils Gösta 1974: "Förord”. In: Vilhelm Ekelund: Ur en scholaris' verkstad. Studier och kommentarier. Lund. 5-7.

Valdén, Nils Gösta 1999: "Kommentar till Veri similia-böckerna”. In: Vilhelm Ekelund: Nordiskt och klassiskt. Veri similia I-II. Lund, xix-xxxix.

Welsch, Wolfgang 1999: "Transculturality - the Puzzling Form of Cultures Today". In: Featherstone, Mike \& Scott Lash (red): Spaces of Culture: City, Nation, World. London. 194-213.

Werin, Algot 1960: Vilhelm Ekelund 1880-1908. Lund.

Werin, Algot 1961: Vilhelm Ekelund 1908-1925. Lund.

Wijkmark, Carl-Henning 1976: "Vilhelm Ekelund och George". In: Ekelundstudier 1912-76.

Lund. 115-125. 